\title{
Effects of the Experience in Using the Third-Party Payment on the Payment Model of Online Shopping
}

\author{
Shwu-Ing $\mathrm{Wu}^{1} \&$ Ya-Chen Chuang ${ }^{1}$ \\ ${ }^{1}$ Department of Business Administration, National Chin-Yi University of Technology, Taiwan, R. O. C \\ Correspondence: Shwu-Ing Wu, Department of Business Administration, National Chin-Yi University of \\ Technology, No. 57, Section 2, Zhongshan Road, Taiping, Taichung, Taiwan, R. O. C. E-mail: \\ wusi@ncut.edu.tw
}

Received: January 30, 2018

doi:10.5539/ijbm.v13n7p107
Accepted: April 30, 2018

Online Published: June 15, 2018

URL: https://doi.org/10.5539/ijbm.v13n7p107

\begin{abstract}
As it is impossible for consumers to conduct a face-to-face transaction in online shopping, both buyers and sellers would mistrust each other and lack a sense of security. To address this problem, people have gradually paid heed to the third-party payment. Targeting at the third-party payment, this study probed into the effects of consumers' perceived risk and benefit of the third-party payment system, social impact and personal involvement in the Internet on the attitude towards the third-party payment system, perceived value and use intention. Moreover, a relational model was established, and the differences between those who had used the third-party payment and those who hadn't were explored. In this study, the convenience sampling was adopted to retrieve 761 valid questionnaire copies. The respondents were divided into two groups according to the experience in using the third-party payment: one had used the third-party payment and the other hadn't. Then, the two groups were compared. The findings showed that there was significant difference between the two groups in three relational paths: (1) for the online shoppers who had used the third-party payment, perceived benefit had stronger influence on use attitude; (2) for the online shoppers who had never used the third-party payment, attitude had greater impact on the use intention of the third-party payment; (3) for the online shoppers who had used the third-party payment, perceived value had more significant effect on the use intention of the third-party payment. The research results also demonstrated that there was some difference in behavioral model between the two groups. These findings can be taken as reference information for the third-party payment enterprises to make strategies.
\end{abstract}

Keywords: Third-Party Payment, perceived risk, perceived benefit, social influence, network involvement, perceived value, attitude, use intention

\section{Introduction}

In recent years, the Internet has been continually and rapidly developed, as Naisbit (1984) put it, computer technology is to the information era what mechanization is to the industrial revolution. Thanks to the convenient access to the Internet, most of the Taiwanese population has become Internet users. The way people receive information has becoming increasingly diverse and faster, and the combination of technological advancement and delivery service has contributed to the prevalence of electronic business. These factors have changed consumer behaviors. There was a great year-by-year growth in the Taiwanese online shopping market. According to the Market Intelligence \& Consulting Institute survey on the mobile shopping among Taiwanese people, the online shopping rate in Taiwan has exceeded 85\% (Market Intelligence \& Consulting Institute, 2016) as a whole. Therefore, online shopping has been popular among consumers for long.

Due to the development of the Internet and scientific technologies, there has been a trend of cooperation between the financial service industry and the technological industry in recent years. The integration of finance and technology has led to the coined word - Fintech, which is the best example of industrial reform. The most dramatic change is the brand-new operation model and the innovative payment. Such change has also accelerated the development of electronic and mobile business. The most frequently-used payment methods for online shopping include the payment on delivery, the ATM transfer, the payment and pickup in supermarket, and the credit card. In addition, there is another payment model - the third-party payment, which emerged in response to the heated wave of online shopping and serves as an option for consumers. The transaction models 
featuring the third-party payment have been used in Europe, the US and Mainland China for long. In contrast, the Taiwanese consumers didn't become aware of the third-party payment system until the rising of Taobao and the emergence of the third-party payment in many online shopping websites in Taiwan in recent years. Before that, such payment was not well received because it was considered as underdeveloped and thought to cause legal problems (Financial Supervisory Commission, 2016). The so-called third-party payment is often used for online shopping. With its cash flow controlled by an impartial and trustworthy third-party platform, it serves as an online service transaction platform which provides safe and fast payment services for both buyers and sellers and reflects the application of Fintech (Kettler, 2017). In an online transaction, buyers would not directly give money to sellers but to the middleman - the third-party payment system, so that buyers would pay for goods and sellers sell goods without worries (Cao, Huang, \& Chai, 2017). Compared with credit card payment and bank-based transfer, the third-party payment is a more convenient transaction model with guarantee. It has been applied to electronic business and mobile payment (Institute for Information Industry, 2015).

The third-party payment is value because it can fill the trust gap between buyers and sellers and facilitate transaction. Such service becomes even more valuable when the risk of transaction between the two is high. Today, the Internet has been frequently utilized, but a survey on the use of wireless network in Taiwan showed that people were highly worried about the privacy of surfing the Internet with mobile devices. One has to offer basic personal information and the information about credit card to use the third-party payment, and it is obvious that consumers are still hesitant to accept the payment (TWNIC, 2016). Privacy, financial safety and trust are all related to consumers' intention of using a third-party payment system. Hence, the effect of network security on the third-party payment is more worthy of discussion.

Lieberman and Stashevsky (2002) believed that consumers would be influenced by benefit and risk in online shopping. Bauer (1960) argued that any consumer behavior might lead to uncertain or unexpected results, so consumers often had to decide which payment was the least risky to reduce uncertainties. Consumers worry that their personal information may be leaked and their financial information may be stolen. According to Luo (2002), enhancing consumers' trust in the Internet could effectively reduce consumers' worry about the leakage of personal information and might strengthen their intention of online shopping. So and Sculli (2002) also noticed that stronger trust could curtail consumers' doubt. Apart from risk, online shoppers also attach importance to benefits. Time saving and convenient use are among the most important benefits (Rohm \& Swaminathan, 2004). It can be seen that consumers are still worried about the hidden risks in the third-party payment and that benefit also influences their use intention. These are the two issues that must be analyzed.

On top of risk and benefit, social influence and network involvement are also the factors that cannot be ignored. Social influence can be divided into two types - normative influence and informational influence. The former means that one would not confirm the accuracy of information and then accept all the information that is presented, so as to meet others' expectation and win other's acceptance. The latter indicates that one believes that the information provided by others is accurate and then accepts it (Deutsch \& Gerard, 1995). Zaichkowsky (1985) pointed it out that involvement indicated that different personal views would lead to different degrees of emphasis on products and that different understanding of products would influence use intention. For that reason, consumers' involvement in products would influence their use motivation. Therefore, social influence and network involvement are also essential for the intention and behavior of using the third-party payment. These are also the issues to be discussed in this study.

According to what has been mentioned above, perceived risk, perceived benefit, social influence and network involvement are the issues that must be explored to understand the intention of using the third-party payment. However, most of the existing academic papers on the third-party payment focus on perceived risk which includes security, trust, convenience and privacy. Despite that many studies have been directed at perceived usability and perceived ease of use in recent years, few studies have been done on such factors as social influence, network involvement and perceived benefit. Hence, this study aims to find out if the above four factors have any effect on the intention of using the third-party payment. Taking the perceived risk, perceived benefit, social influence and consumers' network involvement of the third-party payment as the independent variables, this study probed into consumers' intention of using the third-party payment, with the hope of providing reference information for relevant enterprises to plan the strategies for the third-party payment.

To find out if consumers had the intention of using a new kind of payment, this study compared the group which had used the third-party payment with that which hadn't, so as to figure out consumers' attitudes towards the payment system and different groups' intention of using third-party payment system.

First, this study collected relevant academic papers and theories as the basis of the research structure. Then, the 
questionnaire analysis was conducted to explore the effects of perceived risk, perceived benefit, social influence and network involvement on the perceived value, attitude, intention and actual use of the third-party payment. The population of sampling was the consumers aged over 15 who had experienced online shopping in Taiwan.

\section{Literature Review}

\subsection{Perceived Risk}

The concept of perceived risk was first proposed in the studies on psychology, and it represents a sense of psychological uncertainty. Bauer (1960) pointed it out that consumers would perceive an unexpected sense of uncertainty; hence, their behaviors might lead to displeasure caused by dissatisfaction. It is impossible for consumers to predict results in the purchase of products or services. In face of an uncertain situation, they would feel the so-called perceived risk. Therefore, the risk felt by consumers was not the actual risk perception in the purchase (Biswas, Biswas \& Das, 2006). It symbolizes a sense of uncertainty or the subjective judgment consumers make in risk evaluation and in face of uncertainty (McColl-Kennedy \& Fetter Jr, 2001). Bauer (1960) introduced the concept of perceived risk to the field of marketing management, being the first one to explore consumer behavior from the perspective of perceived risk. Featherman \& Pavlou (2003) argued that perceived risk was the possible loss consumers encountered in the pursuit of their expected results. Jacoby and Kaplan (1972) believed that consumers would feel different perceived risks due to different products, including functional risk, physical risk, financial risk, social risk and psychological risk. Murray \& Schlacter (1990) divided perceived risks into six kinds, such as functional risk, performance risk, physical risk, psychological risk, social risk and convenience risk. For online shoppers, the biggest worry is privacy security problem, which refers to the risk caused by leakage of personal information. Therefore, privacy risk has great effect on online shoppers (Swaminathan et al., 1999; Jarvenpaa et al., 1999; Mooney, 2000).

This study summarized the viewpoints of the above scholars and the perceived risk related to the third-party payment and divided perceived risk into five types, namely, financial risk, functional risk, convenience risk, privacy risk and psychological risk.

\subsection{Perceived Benefit}

In the purchase or use of products, consumers would not only make comments but also consider if products would meet their needs and if the services would generate psychological or functional benefits, or perceived benefits (Eccles, Mort \& Previte, 2006). Park et al. (1986) divided perceived benefit into three kinds: functional benefit means that consumer could obtain benefits; experience benefit indicates delivering self-image and receiving respect from others; symbolic benefit refers to consumers' feeling after consumption or use. Sweeney \& Soutar (2001) also divided benefit into three types, namely, functional benefit, emotional benefit and social benefit. Functional benefit refers to the practical functions of products; emotional benefit focuses on entertainment and experience; social benefit means that products have improved their social images. Maria \& Loureiro (2013) argued that consumers intended to base their use of the third-party payment on the benefits brought by online shopping. Therefore, consumers' perceived benefit of the third-party payment also influenced their use of the third-party payment.

This study summarized the theories about perceived benefit proposed by Park et al. (1986), Sweeney \& Soutar (2001) and designed four benefit dimensions to measure the third-party payment, including functional benefit, experience benefit, symbolic benefit and social benefit.

\subsection{Social Influence}

Social influence refers to one's feeling, indicating that one's physiological state, motivation and emotion, cognition, values, attitude and behavior may be influenced by other factors (Latane, 1981). Interpersonal communication may lead to different thoughts and behavioral intentions (Kelman, 1961; Davis et al, 1989). Personal behavior and decision-making are often influenced by social context (Ajzen \& Fishbein, 1980; Ajzen, 1991). Deutsch \& Gerard (1955) divided social influence into two kinds: (1) normative influence means that one always receive external information to meet others' expectation, win acceptance from others or avoid punishment; (2) informational influence indicates that one receives most information from others when he/she faces uncertainties and must search certainty; aside from reducing his/her fear of uncertainty with the information from others, he/she bases decisions on the information.

In this study, the two social influences - normative influence and informational influence by Deutsch \& Gerard (1955) were taken as the items to measure the social influence of the third-party payment. 


\subsection{Network Involvement}

Zaichkowsky (1985) regarded involvement as "the degree to which one is related to an object according his/her need, values and preference". Barki and Hartwick (1989) believed that involvement represented one's feeling and reflects the importance and correlation of people or events. Laaksonen (1996) defined involvement as one's perception of the importance of an object. In summary, involvement means that one attaches different degrees of importance to different objects. According to the definitions of network and involvement, network involvement can be seen as "the correlation between consumers' adhesion to network and demand for network and the importance of network". Therefore, this study took the consumers' frequency of surfing the Internet and network adhesion as the network involvement indexes of the third-party payment.

\subsection{Perceived Value}

Perceived value is consumers' overall evaluation of benefits and costs (Sirdeshmukh et al., 2002; Robins, 2003). Albrecht (1992) pointed it out that the most important thing in a brand-new environment was to provide consumers with new values. Making consumers perceive different values is the decisive factor which influences the use of a new product or system. Sometimes, consumers' perceived value is more essential than actual benefits (Rizvi, Nazish, \& Sadia, 2011). If the different between benefits and costs is not proportional, it indicates a lower level of perceived value; otherwise, it implies a higher level. In other words, consumers have perceived the value of a product before using it, which would influence their use of the product. Hence, perceived value has a major impact on consumers. If consumers don't have any access to a product, they would develop a feeling about it (Rust \& Oliver, 1993; Sweeney \& Soutar, 2001). Sweeney and Soutar (2001) proposed to measure perceived value from four dimensions - quality value, emotional value, social value and price value. In this study, these four dimensions were adopted to measure the perceived value of the third-party payment.

\subsection{Attitude}

Attitude has always been an important part of psychology, but different people define it in different ways. Thurstone and Thurstone (1941) argued that attitude was one's feeling about and understanding of people, events and objects. Fishbein and Ajzen (1975) defined attitude as one's preference or disgust for something which was based on personal experience. Attitude is also seen as the degree to which one likes or dislikes certain behavior (Ajzen, 1991) as well as one of indispensable factors which influence consumers in their acceptance of a new information system and use system (Taylor \& Todd, 1995; Szajna, 1996). According to the Theory of Reasoned Action (TRA) by Fishbein and Ajzen (1975), attitude would be influenced by external factors, and these factors mainly target at consumers" thought on specific behavior, or "faith". Meanwhile, faith includes cognition and emotion. In other words, consumers' cognitive and emotional preference would influence their use intention and behaviors (Ledbetter, 2009b). Bhattacherjee \& Premkumar (2004) also pointed it out that attitude had significant impact on the intention of using technological systems. Hsu et al. (2007) found in their study that consumers' attitude towards first use would have positive effect on their intention of continual use.

This study summarized the views of above scholars and measured consumers' attitude towards a third-party payment system through the overall evaluation of faith, emotion and cognition and preference.

\subsection{Use Intention}

Intention is the subjective probability for a person to show certain behavior. Use intention can be defined as the probability of consumers' intention of using a product; also, use intention can also be taken as the approximate value of actual use (Kimery \& McCord, 2002; Fishbein \& Ajzen, 1975). Howard (1989) said that users would have different understanding of and attitudes towards products and that the satisfaction, confidence and attitude after using a product would influence their use intention.

According to the technology acceptance model (TAM) proposed by Davis (1986), consumer attitude would have direct impact on their use intention of technology. In order to understand consumers' use of a new thing, one must figure out the intention of the behavior because the follow-up execution is dependent on intention. According to the definition of use intention in the TAM, the intention of using the third-party payment forms when users feel risk, benefit and value of the payment system after online shopping.

In this study, use intention indicated that consumers evaluated the overall benefit, risk and price provided by the third-party payment system in their use of the system and assessed the possibility and probability of using the system according to personal cognition. 


\section{Research Hypotheses}

\subsection{Relationship between Perceived Risk and Consumer Attitude and Perceived Value}

Perceived risk means that consumers may encounter something unexpected in the purchase of products. Therefore, it is highly likely that consumers would have a negative feeling and attitude when they sense an uncertainty that cannot be predicted (Bauer, 1960). Jacoby \& Kaplan (1972) and Murphy \& Enis (1986) put forward five risk dimensions - financial risk, psychological risk, social risk, functional risk and physical risk. In their studies, Stone and Gronhaung (1993) added the sixth one - temporal risk. Zeithaml, Parasurman and Malhotra (2005) considered the privacy risk in the study on network. For the perceived risk of online shopping, the confidentiality and security of personal information is a highly important issue (Langford, 1996). Lim \& Ding (2014) pointed it out in their study that perceived risk was an issue that consumers were highly concerned about. It referred to the risk and sacrifice consumers would feel before taking any action and would affect their attitude; hence, perceived risk had negative impact on attitude. In their study on online shopping, Swaminathan, Elzbieta and Rao (1999) argued that consumers paid the greatest heed to "security of transaction and privacy"; if consumers felt a lower degree of transaction security, their perceived risk would be greater and they would have a weaker use intention. The research results showed that perceived risk had significant negative impact on consumers' attitude towards online services. Therefore, this study made the following hypothesis:

H1a: Consumers' perceived risk of the third-party payment has significant negative effect on their use attitude.

Loh and Ong (1998) pointed it out that information security played a key role in consumers' acceptance of a new system and influenced consumers' evaluation of overall values. Gronroos (2000) believed that perceived value derived from the ratio between the benefits and risks felt by consumers. Tsai, $\mathrm{Wu}$, and $\mathrm{Li}$ (2004) also argued that perceived risk was a spiritual cost for consumers and was tantamount to invisible sacrifice and would have negative impact on perceived value. It can be deducted that perceived risk has significant negative effect on consumers' perceived value. Hence, the following hypothesis was proposed:

H1b: Consumers' perceived risk of the third-party payment has significant negative effect on their perceived value.

\subsection{Relationship between Perceived Benefit and Consumer Attitude and Perceived Value}

Lutz (1991) argued that consumers would show their attitudes towards brands according to the benefits brought by products or services. The more benefits consumers obtain from brands, products and even services, the more they are likely to have a positive attitude. In addition, Bauer et al. (2008) found in their study on the fans of German professional football teams that the more the fans became aware of the benefits they obtained, the more positive attitude they would show towards the teams they supported. Ranganathan and Ganapathy (2002) pointed it out that if a service made online shoppers aware of its benefits, they would have a more positive attitude towards the service. According to this, this study proposed the following hypothesis:

H2a: Consumers' perceived benefit of the third-party payment has significant positive effect on their use attitude.

Lovelock and Wirz (2004) advocated that perceived benefit influenced perceived value. Chen and Dubinsky (2003) found that consumers could achieve benefits from products or services and generate perceived value. The more benefits they acquire, the higher value they will perceive. Therefore, if costs remain unchanged, providing more benefits for consumers will enhance consumers' perceived value (Monroe, 2003). Perceived benefit is the positive feeling of consumers. Moreover, the feeling is not only about the actual functions of products or services but also involves consumers' psychological state. If they perceive more benefits, they would have higher perceived value. Hence, perceived benefit is highly correlated with perceived value. This demonstrates that perceived benefit has positive effect on perceived value. For that reason, this study made the following hypothesis:

H2b: Consumers' perceived benefit of the third-party payment has significant positive effect on their perceived value.

\subsection{Relationship between Social Influence and Consumer Attitude and Perceived Value}

Lascu and Zinkhan (1999) believed that one would grow under different effects in different social circumstances, such as the effects of parents, friends and even cultures and customs. Consumers tend to make decisions that meet public expectation according to social circumstance, which would further influence their attitudes and behaviors. Latane (1981) also argued that one would develop different attitudes because of different social circumstances or others' influence. Society is an essential factor which influences users' attitude. Hou et al. 
(2010) also believed that consumers might change their attitudes due to the influence of others or social circumstances in the use of new products or services. Therefore, this study made the following hypothesis:

H3a: Social influence has significant positive effect on consumers' attitude towards the third-party payment.

Vigneron and Johnson (1999) pointed it out that consumers would have different perceived values due to the influence of surroundings or others' views and behaviors in the purchase of products. According to research investigation, if consumers find that their views are different from that of majority, they would change their views and follow others and have a perceived value different from the previous one (Stafford, 1966). If consumers feel social influence and receive the new information from others, they would change their original perceived value and comment (Eccles, 1983). Chiu and Wang (2008) also said that social influence had impact on consumers' behaviors, choices and values. Therefore, this study proposed the following hypothesis:

H3b: Social influence has significant positive effect on consumers' perceived value of the third-party payment.

\subsection{Relationship between Network Involvement and Consumers' Attitude and Perceive Value}

MacInnis and Park (1991) found in their study that different degrees of involvement led to different attitudes towards products or services and different effects. Also, different extents of involvement would result in different degrees of use, attitudes, personal preferences and even searches and purchases. Swanson (1974) proposed that involvement would influence one's positive attitude towards a network system and increase its use frequency. Ives and Olson (1984) found that a higher degree of involvement would lead to a more positive attitude towards a network system and a stronger willingness to use the system or service and the tendency of continual use of the system. Therefore, the following hypothesis was proposed:

H4a: Consumers' network involvement has significant positive effect on consumers' attitude towards the third-party payment.

According to the Study on the Operation of Travel Agencies and Different Lines of Sightseeing Trains, passengers' involvement in commodities had significant effects on perceived value. The analysis of the involvement scale and the perceived value scale showed that involvement had positive effect on perceived value. With consumption-oriented electronic products, $\mathrm{Hu}$ (2011) explored the relationship among involvement, brand right and interest, perceived risk and customer loyalty and found that involvement and perceived risk had positive effect on customer loyalty and that consumer involvement had significant positive effect on perceived value. Different degrees of network involvement of consumers would lead to different perceived demands, values and objectives in the use of new products or services. Stronger correlation would also contribute to a higher degree of involvement and have positive effect on self-perceived value. According to the above theories, the following hypothesis was proposed:

H4b: Consumers' network involvement has significant positive effect on consumers' perceived value of the third-party payment.

\subsection{Relationship between Consumers' Perceived Value and Their Attitude}

According to Dodds and Monroe (1985), perceived value means that customers would measure the gap between benefits and costs in the purchase of products or services, and a higher perceived value would lead to a stronger attitude and intention of customers. Zeithaml (1988) pointed it out that perceived value depended on the type of product and service as well as personal trait. Dodd, Monore and Grewa (1991) argued that perceived value was the combination of perceived obtained value and transaction value and that the maximum of the combination would enhance consumers' perceived value and positive attitude. Sirdeshmukh et al. (2002) and Robbins (2003) also believed that perceived value was the balance between consumers' obtained benefits and costs. According to the Theory of Planned Behavior (TPB) of Ajzen (1991) and Kimetal (2011), the cognition of perceived value would influence personal emotion and consumer attitude. It was also found in the study by Kwon, Trail and James (2007) that a higher perceived value of consumers would contribute to a more positive attitude towards products or services. Ruiz-Molina and Gil-Saura (2008) also pointed it out that consumers would show a more positive attitude towards suppliers if they had a higher perceived value. Therefore, this study made the following hypothesis:

H5: Consumers' perceived value of the third-party payment has significant positive effect on their attitude towards the third-party payment.

\subsection{Relationship between Consumers' Attitude and Their Use Intention}

Fishbein and Ajzen (1975) believed that attitude was a person's overall evaluation of specific people, events, objects and phenomena. Expressed through words, facial expressions and behaviors, attitude is a behavioral 
intention reaction to people, events, institutions and concepts. Davis (1989) defined the attitude towards technological products as a person's positive or negative feeling about the products and argued that use attitude would generate use intention. According to the study on consumers' intention of using the cloud computing service, use attitude had significant positive effect on use intention. This means that users would show a more positive attitude and a stronger use intention when they perceive that the benefits brought by the cloud computing service outweigh costs. It is obvious that a positive use attitude would enhance consumers' use intention. Therefore, the following hypothesis was proposed:

H6: Consumers' attitude towards the third-party payment has significant positive effect on their use intention.

\subsection{Relationship between Consumers' Perceived Value and Their Use Intention}

As products and services become more diversified, consumers have had more choices. Whether consumers are willing to use a new product or service mainly depends on their perceived value of the product or service. If consumers want to use a product or service, they would evaluate it and predict the value it would bring, which would influence their use intention. According to previous studies, if the value of a product or service was closer to the value expected by consumers, the perceived value of the product or service will be higher and consumers would have a stronger intention of using it (Dodds, Monroe, \& Grewal, 1991). Leppaniemi et al. (2004) and Scharl et al. (2005) probed into consumers' intention of receiving information and how to provide consumers with the most expected information. It was found that consumers would have a higher intention of receiving information if they felt that the information was valuable. For that reason, the following hypothesis was proposed:

H7: Consumers' perceived value of the third-party payment has significant positive effect on their use intention.

\subsection{Effect of the Experience in Using the Third-Party Payment on Payment Model}

Backman and Crompton (1991) and Dick and Basu (1994) argued that loyalty could be divided into two dimensions - behavioral and psychological: behavioral dimension refers to consumers' participation in activities, facilities and frequency of acceptance, showing the consistence and intention of several times of participation; psychological dimension indicates emotional preference. Therefore, if an online shopper has used the third-party payment and is familiar with the payment system, he/she would have a stronger use intention and be more willing to accept it. Conversely, if an online shopper has never used any third-party payment system and is unfamiliar with the payment, he/she would show a weaker use intention. Modahl (2000) also pointed it out that those who had shopped online might have a stronger intention of online shopping. Hence, the online shoppers who had used a third-party payment system may show a stronger use intention. Therefore, the effect of the experience in using the third-party payment on the relationship among such dimensions as consumers' perceived risk, perceived benefit, social influence, network involvement, attitude, perceived value and use intention is the focus of this study. Based on this, the following hypothesis was proposed:

H8: There is significant difference in the influence intensity of different paths between those who have used the third-party payment and those who haven't.

\section{Research Design}

\subsection{Research Framework}

For the first step, relevant academic papers and theories were collected as the basis of the research framework of this study. Then, the questionnaire analysis was conducted to explore the effect of perceived risk, perceived benefit, social influence and network involvement on the perceived value of, attitude towards and intention of using the third-party payment. Moreover, a relevance model was established to analyze the influence of the experience in using the third-party payment on the relational intensity of the model, as is shown in Figure 1. 


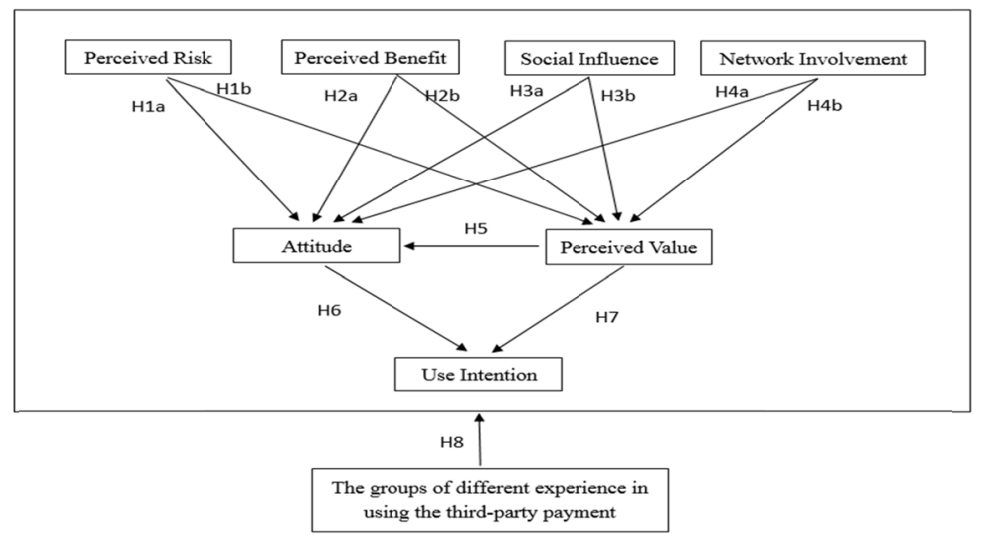

Figure 1. Research Framework

\subsection{Research Method and Procedures}

First, relevant theories and academic papers were collected as the basis of the discussion on the research dimensions, and the questionnaire draft was made. Then, a pretest and a pilot were conducted to modify and confirm the content of the official questionnaire. After that, the questionnaire was adopted for the demonstration to establish the relevance model of consumers' intention of using the third-party payment. Taking the Taiwanese aged 15 as the subjects, this study conducted a convenience sampling investigation where the questionnaire copies were manually distributed. In the process, 800 questionnaire copies were distributed.

\subsection{Sample Structure}

This study discussed the relevance model of online shoppers' intention of using the third-party payment. After 39 questionnaire copies with unreliable and incomplete responses were removed, 761 vallid ones were kept. The retrieval rate of valid questionnaire copies was $95.1 \%$. The retrieved samples were divided into 10 parts for analysis. As far as personal information is concerned, females accounted for $57.4 \%$, In terms of age, those aged from 25 to 34 occupied $35.5 \%$, followed by those aged from 15 to $24(31.0 \%)$. When it comes to residence, those from central Taiwan accounted for $35.2 \%$, followed by those from northern Taiwan (34.0\%). As far as educational background is concerned, those with college education (junior college education) occupied 63.1\%, followed by those with high school education (higher vocational education) (19.7\%). In terms of career, those engaged in the service industry took up $27.6 \%$, followed by those who were students $(23.3 \%)$. When it comes to personal monthly income, those earning a monthly income of NTD 20,001 to NTD 40,000 accounted for 45.7\%, followed by those who earned less than NTD 20,000 (29.4\%). Those who took the Yahoo shopping center as the most frequently-used shopping platform accounted for the largest proportion (36.0\%), and those who adopted the supermarket payment as the most frequently-used payment occupied the largest proportion (41.9\%). Those who had used a third-party payment system took up the largest proportion (54.8\%). Those who took Shopee as the most frequently-used third-party platform accounted for the largest proportion $(25.2 \%)$.

\subsection{Analysis of the Reliability and Validity of the Official Questionnaire}

After the official survey, this study analyzed the reliability and validity of all the dimensions to guarantee the reliability of the questionnaire. In this study, Cronbach's $\alpha$ and the factor analysis were used to evaluate the reliability and validity of the questionnaire. According to Nunnally (1978) and Devellis (1991), if Cronbach's $\alpha$ was above 0.7 , it would indicate that the internal consistency and stability were high and that the research results were reliable. Kerlinger (1978) proposed that the correlation coefficient of item to total needed to be above 0.5 . According to the research results, the Cronbach's $\alpha$ of the overall scale was above 0.7 . As far as individual dimension is concerned, the reliability of network involvement was low, and Cronbach's $\alpha$ was 0.697 (highly approximate to 0.7$)$, meeting the reliability criterion by the scholars $(0.5<\alpha \leq 0.7)$. Moreover, the overall dimension of correlation coefficient of item to total was higher than 0.5 . Therefore, the overall reliability of the questionnaire of this study was high (as is shown in Table 2).

In terms of the validity of questionnaire, this study adopted the factor analysis to test the convergent validity of the questionnaire. According to the principle components analysis (PCA) by Kaiser (1958), the maximum variation method was employed for the factor rotation, and the extracted eigenvalue must be higher than 1 . Meanwhile, the factor loads of the variables of the factor dimensions must be over 0.5 , and the cumulative explained variation must be higher than 0.5. The results showed that Item 6 of perceived risk ("I think the 
transaction based on the third-party payment system has not been popular yet") didn't meet the evaluate rule, so it was removed. Then, the factor analysis was conducted again, and the results showed that the factor loads of the variables in each factor dimension were higher than 0.5 and the cumulative explained variation was over $50 \%$. It is obvious that the questionnaire had high convergent validity. Then, important sub-dimensions were extracted and renamed.

(1) The two factors of perceived risk were named as "factor of psychological risk" and "factor of functional risk" respectively according to the characteristics of the item.

(2) The two factors of perceived benefit were named as "functional benefit" and "social and economic benefit" respectively according to the characteristics of the item.

(3) The two factors of social influence were named as "informative influence" and "normative influence" respectively according to the characteristics of the item.

(4) The two factors of network involvement were named as "dependence" and "adhesion" respectively according to the characteristics of the item.

Additionally, the two indexes - potential variable composite reliability $(\mathrm{CR})$ and the average variance extracted (AVE) were used to evaluate the reliability and validity in this study. That CR needed to be higher than 0.6 and AVE must be over 0.5, which was proposed by Fornell \& Larcker (1981), was taken as the evaluation criterion. According to the research results, the CRs of the factors ranged from 0.8421 to 0.9713 , all being higher than 0.6. Hence, the internal consistency of the factor dimensions of this study was high. The AVEs ranged from 0.5906 to 0.8496 , all being above 0.5 . This means that the convergent validity of this study was high.

Table 1. Analysis of the reliability and validity of the official questionnaire

\begin{tabular}{|c|c|c|c|c|c|c|c|c|}
\hline Factor and item & Mean & $\begin{array}{l}\text { Item-to-total } \\
\text { correlation } \\
\text { coefficient }\end{array}$ & $\begin{array}{l}\text { Factor } \\
\text { loading }\end{array}$ & Eigenvalue & $\begin{array}{l}\text { Cumulative } \\
\text { Explained } \\
\text { Variation (\%) }\end{array}$ & $\begin{array}{l}\text { Cronbach } \\
\alpha \text { value }\end{array}$ & $\begin{array}{l}\text { Component } \\
\text { reliability } \\
(\mathrm{CR})\end{array}$ & $\begin{array}{l}\text { Average } \\
\text { variance } \\
\text { extracted } \\
\text { (AVE) }\end{array}$ \\
\hline \multicolumn{9}{|c|}{ Perceived risk (psychological risk) } \\
\hline $\begin{array}{l}\text { Personal transaction } \\
\text { information may be } \\
\text { leaked in the use of a } \\
\text { third-party payment } \\
\text { system. }\end{array}$ & 5.1840 & 0.834 & 0.918 & 5.861 & 65.124 & 0.929 & 0.9068 & 0.6234 \\
\hline $\begin{array}{l}\text { Personal transaction } \\
\text { information may be } \\
\text { stolen in the use of a } \\
\text { third-party payment } \\
\text { system. }\end{array}$ & 5.2313 & 0.805 & 0.903 & & & & & \\
\hline $\begin{array}{l}\text { Financial information } \\
\text { may be leaked in the } \\
\text { use of a third-party } \\
\text { payment system. }\end{array}$ & 4.7727 & 0.801 & 0.811 & & & & & \\
\hline $\begin{array}{l}\text { I feel unsecure to use a } \\
\text { third-party payment } \\
\text { system. }\end{array}$ & 4.6032 & 0.821 & 0.753 & & & & & \\
\hline $\begin{array}{l}\text { There is the risk of } \\
\text { financial loss in the use } \\
\text { of a third-party } \\
\text { payment system. }\end{array}$ & 4.4757 & 0.770 & 0.713 & & & & & \\
\hline $\begin{array}{l}\text { I feel pressure to use a } \\
\text { third-party payment } \\
\text { system. }\end{array}$ & 4.1853 & 0.720 & 0.591 & & & & & \\
\hline \multicolumn{9}{|c|}{ Perceived risk (functional risk) } \\
\hline $\begin{array}{l}\text { It is not easy to use a } \\
\text { third-party payment }\end{array}$ & 3.7963 & 0.884 & 0.902 & 1.317 & 79.755 & 0.925 & 0.9159 & 0.7841 \\
\hline
\end{tabular}




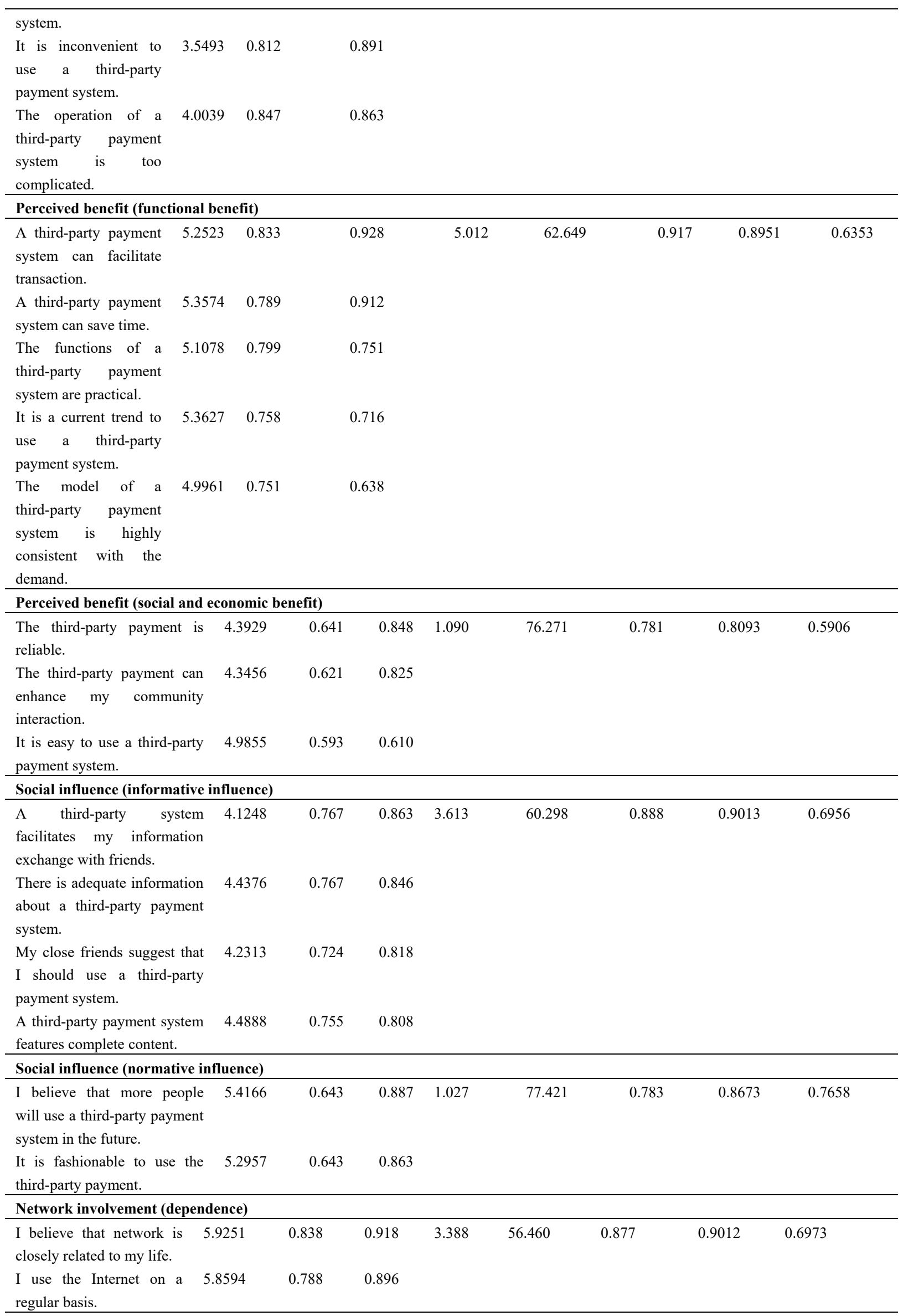




\begin{tabular}{|c|c|c|c|}
\hline $\begin{array}{l}\text { There is adequate } \\
\text { information about a } \\
\text { third-party system. }\end{array}$ & 5.6597 & 0.739 & 0.805 \\
\hline $\begin{array}{l}\text { The quality of a website } \\
\text { has effect on the time I } \\
\text { spend on the Internet. }\end{array}$ & 5.7398 & 0.580 & 0.704 \\
\hline
\end{tabular}

spend on the Internet.

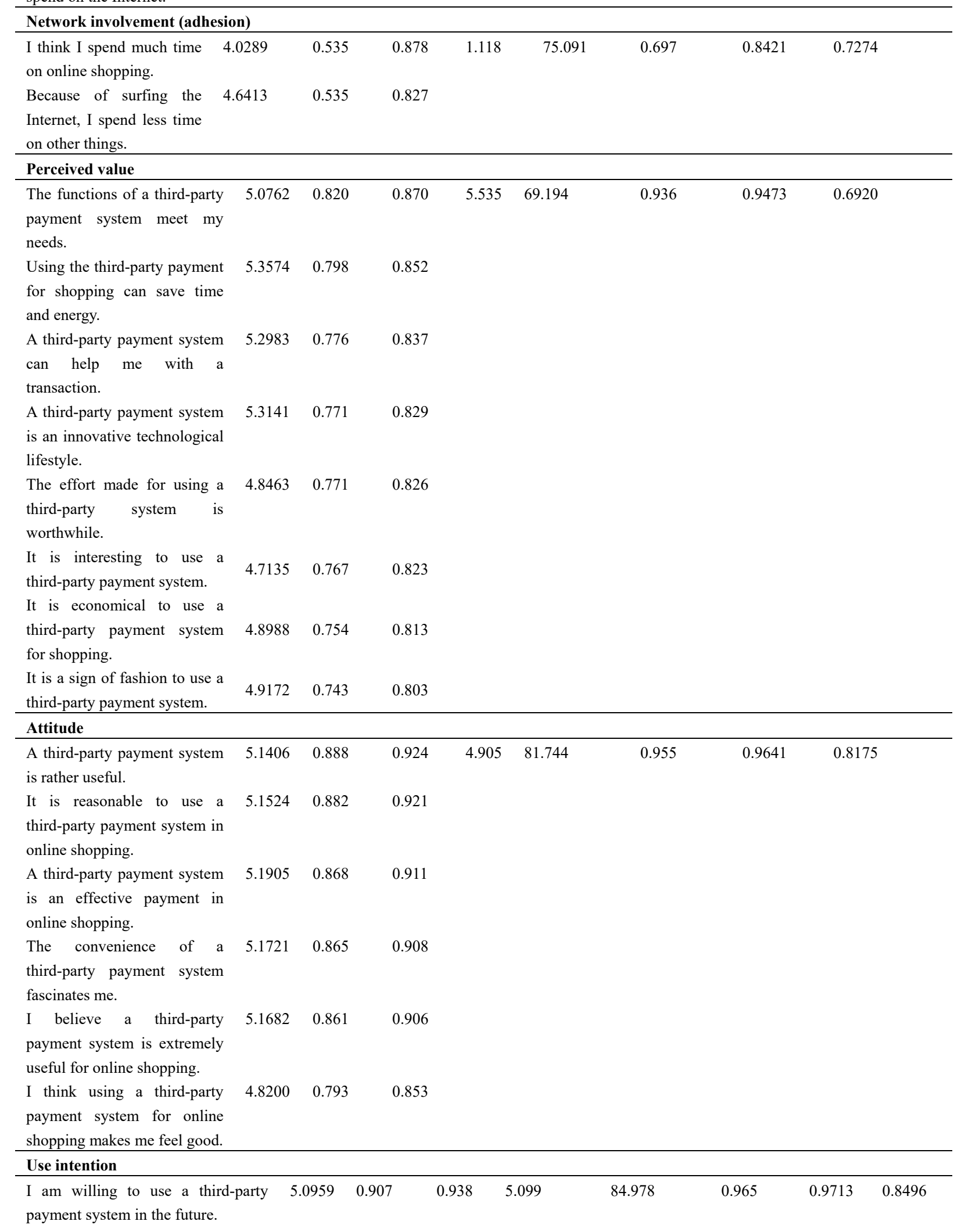




\begin{tabular}{|c|c|c|c|}
\hline $\begin{array}{l}\text { I have a strong intention of using the } \\
\text { third-party payment for online } \\
\text { shopping. }\end{array}$ & 4.8292 & 0.896 & 0.928 \\
\hline $\begin{array}{l}\text { I would think of using a third-party } \\
\text { payment system when shopping } \\
\text { online. }\end{array}$ & 4.8068 & 0.896 & 0.928 \\
\hline $\begin{array}{l}\text { I would recommend others to use a } \\
\text { third-party payment system. }\end{array}$ & 4.8515 & 0.884 & 0.921 \\
\hline $\begin{array}{l}\text { If necessary, I am willing to use a } \\
\text { third-party payment system. }\end{array}$ & 5.1919 & 0.869 & 0.910 \\
\hline $\begin{array}{l}\text { A third-party payment system would } \\
\text { strengthen my transaction intention. }\end{array}$ & 4.7779 & 0.864 & 0.905 \\
\hline
\end{tabular}

\subsection{Confirmatory Factor Analysis}

To demonstrate the effectiveness of the dimensions, this study adopted AMOS to the confirmatory factor analysis (CFA) of the measurement model consisting of seven dimensions, namely, the perceived risk and perceived benefit of third-party payment system, social influence, the network involvement of consumers, and consumers' perceived value, attitude and intention of using the third-party payment. Carmines and MacIver (1981); Hu and Bentler (1999) suggested that the fit index of the model must meet the ideal standard that the ratio of Chi-square value to the degree of freedom was no higher than 3 and that GFI, AGFI, NFI and CFI must be higher than 0.9, and RMR and RMSEA must be lower than 0.05. Bagozzi and Yi (1988) and Jarvenpaa, S.L., et al. (1999) also suggested that the ratio of $x^{2} /$ d.f. must be lower than 5 and that GFI and AGFI must be over 0.8 . McDonald and Ho (2002), however, believed that an acceptable model fit threshold was that RMR and RMSEA were lower than 0.08. According to the research results, the fit indexes of the overall measurement model were as follows: $x^{2} /$ d.f. was 3.328; GFI; 0.904; AGFI, 0.864; NFI, 0.957; RFI, 0.943; CFI, 0.970; RMSEA, 0.055; RMR, 0.069. It can be seen that the fit of the measurement model was acceptable. Therefore, the fit of the measurement model of this study was good, which means that the measurement indexes had the construction validity and measurement effectiveness.

\subsection{Comparative Analysis of Multi-Group Competing Model}

The 761 valid questionnaire copied were divided into two groups according to the experience in using the third-party payment. The number of those who had used the third-party payment was 417 , while that of those who hadn't was 344.

AMOS was adopted for the intergroup model comparison between the two groups to find out if the experience of using the third-party payment had significant effect on the relationship among the dimensions. The fit indexes of the competition model were as follows: $x^{2} /$ d.f. was 2.669 ; GFI, 0.867; AGFI, 0.813; NFI, 0.924; RFI, 0.901; CFI, 0.951 ; RMSEA, 0.047 . This shows that the fit of competition model of this study is high; hence, the model could be accepted. The results and explanations of the analysis are as follows: (e.g., Table 2):

1) There was no significant difference ( $\mathrm{t}=-1.32)$ in the effect of perceived risk on attitude (H1a) between the two groups. For both groups, the effect on the path was significantly negative; therefore, the perceived risk of the third-party payment would have significant negative effect on the use attitude of online consumers. As far as the influence coefficient is concerned, the perceived risk of the third-party payment of the online shoppers of the two groups had influence on use attitude. This indicates that a lower risk would equip consumers with a positive attitude towards the payment system.

2) There was no significant difference $(t=-0.343)$ in the effect of perceived risk on perceived value $(\mathrm{H} 1 \mathrm{~b})$ between the two groups. The effect of the online shoppers who had used the third-party payment on this path was insignificant, while that of those who hadn't was significantly negative. For the online shoppers who hadn't used the payment, a lower risk of the third-party payment would enhance perceived value and bring positive comments and responses.

3) There was significant difference $(t=2.049)$ in the effect of perceived benefit on attitude (H2a) between the two groups. The effect of both groups on this path was positive, and the influence coefficient of the group who had used the third-party payment was higher. This indicates that more benefits would motivate online shoppers to develop a more positive attitude towards the third-party payment.

4) There was no significant difference $(t=1.18)$ in the effect of perceived benefit on perceived value $(\mathrm{H} 2 \mathrm{~b})$ 
between the two groups. In term of influence coefficient, both groups showed positive influence. This means that more benefits would enhance consumers' perceived value of the third-party payment.

5) There was no significant difference $(t=-1.208)$ in the effect of social influence on attitude (H3a) between the two groups. The effect of both groups on this path was significantly positive, which indicates that online shoppers would develop different attitudes towards the payment system because of their circumstances or their friends who were using the third-party payment.

6) There was no significant difference $(t=-0.925)$ in the effect of social influence on perceived value (H3b) between the two groups. The effect of both groups on this path was significantly positive, which means that online shoppers would have positive perceived value of the system because it would bring them authority and status.

7) There was no significant difference $(t=0.143)$ in the effect of network involvement on perceived value (H4a) between the two groups. The effect of both groups on this path was significantly positive, which indicates that the more frequently online shoppers use the network or the more they rely on the network, the more positive attitude they would develop towards the third-party payment.

8) There was no significant difference $(t=-0.026)$ in the effect of network involvement on perceived value (H4b) between the two groups. The effect of both groups on this path was significantly positive, which means that the more frequently online shoppers use the network or the more they rely on the network, the more perceived value they would have.

9) There was no significant difference ( $t=0.373)$ in the effect of perceived value on attitude (H5) between the two groups. The effect of the online shoppers who had used the third-party payment on this path was insignificant, while that of those who hadn't was significantly positive. This shows that the online shoppers who have never used the third-party payment would have a more positive attitude if they perceive higher value.

10) There was significant difference ( $t=-3.829)$ in the effect of attitude on use intention (H6) between the two groups. The effect of the online shoppers who had used the third-party payment on this path was insignificant, while that of those who hadn't was significantly positive. This demonstrates that the online shoppers who have never used the third-party payment would have a stronger use intention if they have a more positive attitude towards the third-party payment.

11) There was significant difference $(t=3.355)$ in the effect of perceived value on use intention (H7) between the two groups. The effect of the online shoppers who had used the third-party payment on this path was significantly greater than that of those who hadn't. This means that the online shoppers who have used the third-party payment would have a higher perceived value of the payment; hence, they would have a stronger intention of using the payment and would be even willing to continue to use it in the future.

According to what has been mentioned above, there was significant difference in three items of the path intensity among the dimensions for the two online shopper groups. This indicates that different consumers' experience in using the third-party payment would lead to significant difference in the relational intensity of some paths. Therefore, $\mathrm{H} 8$ is partially supportive. The conclusion is that the experience in using the third-party payment indeed causes the difference in relational structure. This is an important finding of this study.

Table 2. Comparative analysis of the multi-group competing model

\begin{tabular}{|c|c|c|c|}
\hline \multirow{2}{*}{ Path } & \multicolumn{2}{|c|}{ Evaluation value of standard parameters } & \multirow{2}{*}{$\begin{array}{l}\text { Comparative results of } \\
\text { the T test } \\
\text { used vs. haven't used }\end{array}$} \\
\hline & $\begin{array}{l}\text { Group who have used the } \\
\text { third-party payment }\end{array}$ & $\begin{array}{l}\text { Group who haven't used } \\
\text { the third-party payment }\end{array}$ & \\
\hline $\begin{array}{l}\text { H1a : Perceived risk of the third-party payment } \rightarrow \\
\text { Attitude. }\end{array}$ & $-0.135 * * *$ & $-0.145^{* * *}$ & -1.32 \\
\hline $\begin{array}{l}\text { H1b : Perceived risk of the third-party payment } \rightarrow \\
\text { Perceived value }\end{array}$ & -0.013 & $-0.067^{*}$ & -0.343 \\
\hline $\begin{array}{l}\text { H2a : Perceived benefit of the third-party payment } \\
\rightarrow \text { Attitude }\end{array}$ & 0.104 & 0.003 & $2.049 * *$ \\
\hline $\begin{array}{l}\mathrm{H} 2 \mathrm{~b}: \text { Perceived benefit of the third-party payment } \\
\rightarrow \text { Perceived value. }\end{array}$ & 0.095 & 0.040 & 1.18 \\
\hline H3a : Social influence $\rightarrow$ Attitude & $0.482 *$ & $0.381 * *$ & -1.208 \\
\hline
\end{tabular}




\begin{tabular}{llll}
\hline H3b : Social influence $\rightarrow$ Perceived value & $0.814^{* * *}$ & $0.810^{* * *}$ & $\mathbf{- 0 . 9 2 5}$ \\
H4a : Network involvement $\rightarrow$ Attitude & $0.238^{* *}$ & $0.208^{* *}$ & $\mathbf{0 . 1 4 3}$ \\
H4b : Network involvement $\rightarrow$ Perceived value & $0.353^{* * *}$ & $0.393^{* * *}$ & $\mathbf{- 0 . 0 2 6}$ \\
H5 : Perceived value $\rightarrow$ Attitude & 0.300 & $0.458^{* *}$ & $\mathbf{0 . 3 7 3}$ \\
H6 : Attitude $\rightarrow$ Use intention & 0.094 & $0.531^{* * *}$ & $\mathbf{- 3 . 8 2 9 * * *}$ \\
H7 : Perceived value $\rightarrow$ Use intention & $0.799^{* * *}$ & $0.302^{* * *}$ & $\mathbf{3 . 3 5 5}$ ***
\end{tabular}

$\mathrm{H} 8$ : There is significant difference in the influence intensity of different paths between those who have used the third-party payment

partially supported and those who haven't.

Indicators of Model Fitness

\begin{tabular}{|c|c|c|c|c|c|c|c|c|c|c|}
\hline$x^{2}$ & d.f. & $\mathrm{P}$ values & $x^{2} /$ d.f. & RMR & GFI & AGFI & NFI & RFI & CFI & RMSEA \\
\hline 1542.745 & 578 & 0.000 & 2.669 & 0.169 & 0.867 & 0.813 & 0.924 & 0.901 & 0.951 & 0.047 \\
\hline
\end{tabular}

\section{Conclusion and Suggestions}

\subsection{Conclusion}

According to the views of the consumers who had shopped online and relevant empirical studies, this study explored the effect of consumers' perceived risk, perceived benefit, social influence and network involvement of the third-party payment on use attitude and perceived value and the effect of perceived value and use attitude on the use intention of the third-party payment. Moreover, a relational model was established to compare the group who had used the payment with that who hadn't. The following conclusions have been drawn:

1) For "the online shoppers who have used the third-party payment", social influence had the greatest effect on the perceived value of the third-party payment. This indicates that online shoppers pay attention to their friends' views or feel that using the payment system is fashionable in the social context. Therefore, social influence would effectively enhance online shoppers' perceived value of the third-party payment. The second greatest effect was that of perceived value on use intention. For the online shoppers who had use the payment, if they have higher value in the use of the payment, they would have a stronger use intention. Hence, perceived value is indispensable for the online shoppers who have used the third-party payment.

2) For "the online shoppers who have never used the third-party payment", social influence had the greatest effect on the perceived value of the third-party payment. This is the same with that of those who had used the third-party payment. Hence, the more online shoppers feel social influence, the more they would develop the perceived value of the third-party payment. The second greatest effect was that of attitude on use intention. This is different from that of the group who had used the payment. For the group that hadn't used the payment, if a third-party payment system equipped them with a more positive attitude, they would have a stronger use intention and attempt to use it.

3) For both groups, the effect of perceived risk on attitude was significantly negative. This shows that if online shoppers had perceived risk of the third-party payment, they would develop a negative attitude toward the payment system.

4) For both groups, the effect of network involvement on perceived value was significantly positive. This indicates that online consumers would have a more positive value concept of the third-party payment if they used the network on a more regular basis. Both function and information would effectively motivate the positive cognition of online shoppers.

5) For both groups, the effect of perceived value on use intention was significantly positive, especially the group who had used the payment. This means that if the third-party payment system brought online shoppers greater value perception, it would effectively motivate online shoppers' intention of using the third-party payment.

\subsection{Significance in Management}

According to the linear structure model of this study, there were both similarities and differences between the group who had used the third-party payment and who hadn't. Therefore, the following suggestions on management were proposed: 
The online shoppers who have used the third-party payment would pay more attention to perceived value. In this aspect, enterprises need to make online shoppers feel it worthwhile to use the third-party payment. Apart from making consumers feel that they are fashionable, enterprises can establish an encryption system to protect the personal information of consumers in a more effective way. Also, they can enhance the privacy of the payment system to reduce consumers' anxiety and effectively strengthen their positive attitude towards the third-party payment and then enhance consumers' perceived value, increasing consumers' trust in the third-party payment. Moreover, consumers would keep using the payment.

Probably due to the less access to the information about the third-party payment, the online shoppers who have never used the third-party payment show a conservative attitude towards the payment. Hence, the enterprises managing the third-party payment need to provide more information so that consumers will become more conscious of the advantages of the payment system and have a basic understanding of the system. If consumers are led to use the payment system and are offered the Q\&A service, they would have a more positive attitude towards the third-party payment and a higher perceived value.

For the two groups, the effect of perceived value on use intention was very significant. This shows that if consumers feel a higher value, they will have a stronger use intention. Therefore, enterprises should manage to provide more value. For instance, they can popularize the payment system featuring diverse functions and stability, so that consumers would have a higher perceived value and then have a stronger intention of using the third-party payment.

\subsection{Research Limitations and Suggestions}

In recent years, the third-party payment has been gradually popularized in Taiwan. But the payment system has been well developed and popularized in some countries. Therefore, it is suggested that future studies should expand the research scope and discuss the post-operation satisfaction. Also, the in-depth interview can be adopted to interview the consumers who have used the payment system, so as to further explore the issues about the third-party payment.

With the increasing technological innovation and diversification, there may be difference in the understanding of and attention to a new payment among consumers. Hence, it is suggested that more payment systems should be added for comparative analysis. Also, different consumer groups can be compared to further diversify the application of the relational model of this study and enhance research value.

\section{References}

Ajzen, I. (1991). The theory of planned behavior. Organizational Behavior and Human Decision Processes, 50(2), 179-211. https://doi.org/10.1016/0749-5978(91)90020-T

Ajzen, I., \& Fishbein, M. (1980). Understanding Attitudes and Predicting Social Behaviour. Englewood Cliffs, NJ: Prentice Hall.

Albrecht, K. (1992). The Only Thing That Matters, Executive Excellence. New York: Harper Business, 9, 7-7.

Allport, G. W. (1935). Attitudes, In Handbook of Social Psychology. Clark Univ. Press.

Bagozzi, R. P., \& Yi, Y. (1988). On the evaluation of structural equation models. Journal of the Academy of Marketing Science, 16(1), 74-94.

Barki, H. \& Hartwick, J. (1989). Rethinking the concept of user involvement. MIS Quarterly, 13, 53-63.

Bauer, H. H., Stokburger-Sauer, N. E., \& Exler, S. (2008). Brand image and fan loyalty in professional team sport: A refined model and empirical assessment. Journal of Sport Management, 22, 205-226. https://doi.org/10.1123/jsm.22.2.205

Bauer, Raymond A. (1960) Consumer behavior as risk taking. Dynamic Marketing for a Changing World Proceedings of the 43rd Conference of the American Marketing Association. R. S. Hancock. Chicago: American Marketing Association.

Bhattacherjee, A., \& Premkumar, G. (2004). Understanding changes in belief and attitude toward information technology usage: a theoretical model and longitudinal test. MIS Quarterly, 28(2), 229-254.

Biswas, D., Biswas, A., \& Das, N. (2006). The differential effects of celebrity and expert endorsements on consumer risk. Journal of Advertising, 35(2), 17-31.

Cao, L., Huang, G., \& Chai, W. (2017). A knowledge discovery model for third-party payment networks based on rough set theory. Journal of Intelligent \& Fuzzy Systems, 33(1), 413-421. https://doi.org/10.3233/JIFS-161738

Carmines, E. G. and McIver, JP (1981). Analyzing Models with Unobserved Variables: Analysis of Covariance Structures. Social Measurement: Current Issues. Beverly Hills, CA: Sage Publications, 65-115. 
Chen, Z., \& Dubinsky, A. J. (2003). A conceptual model of perceived customer value in e-commerce: A preliminary investigation. Psychology and Marketing, 20(4), 323-347.

Chiu, C.M. \& Wang, E.T.G. (2008). Understanding web-based learning continuance intention: The role of subjective task value. Information \& Management, 45(3), 194-201. https://doi.org/10.1016/j.im.2008.02.003

Davis, F. D., Bagozzi, R. P., \& Warshaw, P. R. (1989). User acceptance of computer technology: A comparison of two theoretical models. Management Science, 35, 982-1003. https://doi.org/10.1287/mnsc.35.8.982

Davis, F.D. (1989). Perceived usefulness, perceived ease of use, and user acceptance of information technology. MIS Quarterly, 13, 319-340. https://doi.org/10.2307/249008

De Vellis, R. F., \& Dancer, L. S. (1991). Scale development: theory and applications. Journal of Educational Measurement, 31(1), 79-82.

Deutsch, M. \& Gerard, H. B. (1955). A study of normative and informational social influences upon individual judgment. Journal of Abnormal and Social Psychology, 51(3), 629-636.

Dodds, W. B., \& Monroe, K. B. (1985). The effect of brand and price information on subjective product evaluations. NA-Advances in Consumer Research, 12(1), 85-90.

Dodds, W. B., K. B. Monroe and D. Grewal (1991). Effects of price, brand and store information on buyers' product evaluations. Journal of Marketing Research, 28(3), 307-319 https://doi.org/10.2307/3172866

Drennan, J., Mort, G. S. \& Previte, J. (2006). Privacy, risk perception, and expert online behavior: An exploratory study of household end users. Journal of Organizational and End User Computing, 18(1), 1-22.

Eccles, J. S. (1983). Expectancies, Values and Academic Behaviors. San Francisco, Calif: Freeman.

Featherman, M. A. \& Pavlou, P. A. (2003). Predicting e-services adoption: a perceived risk facets perspective. International Journal of Human-Computer Studies, 59(4), 451-474. https://doi.org/10.1016/S1071-5819(03)00111-3

Financial Supervisory Commission (2016). The FSC Actively Promotes Domestic Mobile Payment Services. Retrieved from https://www.fsc.gov.tw/en/home.jsp?id=74\&parentpath=0,2\&mcustomize=multimessage view.jsp\&dataser no $=201604120003 \&$ aplistdn $=\mathrm{ou}=$ bulletin, $\mathrm{ou}=$ multisite, $\mathrm{ou}=$ english, $\mathrm{ou}=\mathrm{ap}$ root $, \mathrm{o}=\mathrm{fsc}, \mathrm{c}=\mathrm{tw} \& \mathrm{dtable}=$ Bulletin

Fishbein, M. \& Ajzen, I. (1975). Belief, Attitude, Intention and Behavior: An Introduction to Theory and Research. Addison-Wesley, Reading, MA.

Fornell, C. R., \& Larcker, F. F. (1981). Structural equation models with unobservable variables and measurement error. Journal of Marketing Research, 18, 39-51. https://doi.org/10.2307/3150980

Forza, C., \& Filippini, R. (1998). TQM impact on quality conformance and customer satisfaction: a causal model. $\begin{array}{lllll}\text { International Journal of Production } & \text { Economics, } & 55(1), & \text { 1-20. }\end{array}$ https://doi.org/10.1016/S0925-5273(98)00007-3

Gronroos, C. (2000). Service Management and Marketing: A Customer Relationship Approach (2nd ed.). Wiley: Chichester.

Hair, J. F., Tatham, R. L., Anderson, R. E., \& Black, W. (2006). Multivariate Data Analysis (4th ed.). New Jersey: Prentice Hall.

Howard, John A. (1989). Consumer Behavior in Marketing Strategy. Publisher: Prentice Hall.

Hsu, M. H., Ju, T. L., Yen, C. H., \& Chang, C. M. (2007). Knowledge sharing behavior in virtual communities: The relationship between trust, self-efficacy, and outcome expectations. International Journal of Human-Computer Studies, 65(2), 153-169. https://doi.org/10.1016/j.ijhcs.2006.09.003

Hu \& Bentler Caverly, D. C. (2003). Techtalk: how technology has changed developmental education. Journal of Developmental Education, 27, 38-39.

$\mathrm{Hu}$, Y. J. (2011). Exploring the relationship between customer involvement, brand equity, perceived risk and customer loyalty: the case of electrical consumer products. International Journal of Organizational Innovation, 14(1), 111-127.

Institute for Information Industry (2013). Safeguard the Backdoor of Information Security. Retrieved from https://web.iii.org.tw/Operation/FocusDtl.aspx?f_sqno $=/ \mathrm{QHg} / \mathrm{wVxPKX}$ 0751TWS4vNA_\&fm_sqno $=13$

Ives, B., \& Olson, M. H. (1984). User involvement and MIS success: A review of research. Management Science, 30(5), 586-603. https://doi.org/10.1287/mnsc.30.5.586

Jacoby, J. and Kaplan, L.B. (1972). The components of perceived risk. Proceedings of the Annual Conference of the Association for Consumer Research, 10, 382-393. 
Jarvenpaa, S. L., Tractinsky, N., \& Saarinen, L. (1999). Consumer trust in an internet store: A cross-cultural validation. Journal of Computer-Mediated Communication, 5(2), 1-35. https://doi.org/10.1111/j.1083-6101.1999.tb00337.x

Kaiser, H. F. (1958). The varimax criterion for analysis rotation in factor analysis. Psychometrika, 23(3), 187-200.

Kelman, H. C. (1961). Processes of opinion change. Public Opinion Quarterly, 2, 51-60. https://doi.org/10.1086/266996

Kerlinger, F. N. (1978). Foundation of Behavioral Research. New York: McGraw-Hill.

Kettler, B. (2017). Cutting Out the Middleman: Holding Third-Party Payment Processors Liable for the Acts of Their Merchant Clients. Georgetown Law Journal, 105(6), 1721-1759.

Kimery, K. M. and McCord, M. (2002). Third-party assurances: Mapping the road to trust in e-retailing. Journal of Information Technology Theory and Application, 4(2), 63-82.

Kwon, H.H., Trail, G.T., \& James, J.D. (2007). The mediating role of perceived value: Team identification and purchase intention of team-licensed apparel. Journal of Sport Management, 21(4), 540-554. https://doi.org/10.1123/jsm.21.4.540

Laaksonen, P. (1996). Consumer Involvement: Concepts and Research. The Journal of Consumer Affairs. 30(2), 482-485.

Langford, D. (1996). Ethics and the Internet: Appropriate behavior in electronic communication. Ethics \& Behavior, 6(2), 91-106. http://dx.doi.org/10.1207/s15327019eb0602_2

Lascu D.N., \& Zinkhan G. (1999). Consumer conformity: Review and applications for marketing theory and practice. Journal of Marketing Theory and Practice, 7(3), 1-12. http://dx.doi.org/10.1080/10696679.1999.11501836

Latane, B. (1981). The psychology of social impact. American Psychologist, 36(4), 343-356.

Ledbetter, A. M. (2009b). Measuring online communication attitude: Instrument development and validation. Communication Monographs, 76(4), 463-486. http://dx.doi.org/10.1080/03637750903300262

Leppaniemi, M., Karjaluoto, H. \& Salo, J. (2004). The success factors of mobile advertising value chain. E-Business Review, 4(1), 93-97.

Lieberman, Y. \& Stashevsky, S. (2002). Perceived risks as barriers to Internet and e-commerce usage. Qualitative Market Research: An International Journal, 5(4), 291-300. https://doi.org/10.1108/13522750210443245

Lim, W. M., \& Ding, H. T. (2014). Consumer acceptance and continuance of online group buying. Journal of Computer Information Systems, 54(3), 87-96. http://dx.doi.org/10.1080/08874417.2014.11645707

Loh, L. and Ong, Y. S. (1998). The adoption of Internet-based stock trading: A conceptual framework and empirical results. Journal of Information Technology, 13(2), 81-94.

Loureiro, S. M. C. (2013). The effect of perceived benefits, trust, quality, brand awareness/associations and brand loyalty on internet banking brand equity. International Journal of Electronic Commerce Studies, 4(2), 139.

Lovelock, C., \& Wirtz, J. (2004). Services Marketing: People, Technology, Strategy. New York: Prentice Hal.

Luo, Xueming. (2002). Trust production and privacy concerns on the Internet A framework based on relationship marketing and social exchange theory. Industrial Marketing Management, 31, 111-118. https://doi.org/10.1016/S0019-8501(01)00182-1

Lutz, R. J. (1991). The role of attitude theory in marketing. In T. S. Robertson \& H. H. Kassarjian (Eds.), Handbook of Consumer Behavior (pp. 317-339). Englewood Cliffs, NJ: Prentice-Hall.

MacInnis, D. J., \& Park, C. W. (1991). The differential role of characteristics of music on high-and low-involvement consumers' processing of ads. Journal of Consumer Research, 18(2), 161-173. https://doi.org/10.1086/209249

Market Intelligence \& Consulting Institute (2016). Mobile Payment Consumer Survey in Taiwan: Intention Analysis of Demographic Groups. http://mic.iii.org.tw/english/reports_detail.aspx?sqno=10901

McColl-Kennedy, J.R., Fetter Jr, R.E. (2001). An empirical examination of the involvement to external search relationship in services marketing. Journal of Services Marketing, 15(2), 82-98. https://doi.org/10.1108/08876040110381337

McDonald, R. P., \& Ho, M. H. R. (2002). Principles and practice in reporting structural equation analyses. Psychological Methods, 7(1), 64. http://dx.doi.org/10.1037/1082-989X.7.1.64 
Modahl, M. (2000). Now or Never. How Companies must Change Today to Win the Battle for the Internet Consumer. London: Orion.

Monroe, K. B. (2003). Pricing: Making Profitable Decisions. Boston, MA: McGraw-Hill Co.

Murphy, P. E., \& Enis, B. M. (1986). Classifying Products Strategically. Journal of Marketing, 50(3). https://doi.org/10.2307/1251583

Murray, K. B., \& Schlacter, J. L. (1990). The impact of services versus goods on consumers: Assessment of perceived risk and variability. Journal of the Academy of Marketing Science, 18, 51-65. https://doi.org/10.1007/BF02729762

Nazish, Z. R., \& Sadia, M. (2011). Impact of sales promotion on organizations' profitability and consumer's perception in Pakistan. Interdisciplinary Journal of Contemporary Research in Business, 3(5), 296-310.

Nunnally, J. C. (1978). Psychometric Theory. New York: McGraw-Hill.

Park, C. W., Jaworski, B. J., \& Maclnnis, D. J. (1986). Strategic brand concept-image management. Journal of Marketing, 50(4), 135-145. https://doi.org/10.2307/1251291

Ranganathan, C., \& Ganapathy, S. (2002). Key dimensions of business-to-consumer web sites. Information \& Management, 39(6), 457-465. https://doi.org/10.1016/S0378-7206(01)00112-4

Robins, F. (2003). The marketing of 3G. Marketing Intelligence \& Planning, 21(6), 370-378. https://doi.org/10.1108/02634500310499239

Rohm, A. J., \& Swaminathan, V. (2004). A typology of online shoppers based on shopping motivations. Journal of Business Research, 57(7), 748-757. https://doi.org/10.1016/S0148-2963(02)00351-X

Ruiz-Molina, M. E., \& Gil-Saura, I. (2008). Perceived value, customer attitude and loyalty in retailing. Journal of Retail \& Leisure Property, 7(4), 305-314. https://doi.org/10.1057/rlp.2008.21

Rust, R. T., \& Oliver, R. L. (Eds.). (1993). Service Quality: New Directions in Theory and Practice. Sage Publications.

Scharl, A., Dickinger, A., \& Murphy, J. (2005). Diffusion and success factors of mobile marketing. Electronic Commerce Research and Applications, 4(2), 159-173. https://doi.org/10.1016/j.elerap.2004.10.006

Sirdeshmukh, D., Singh, J., \& Sabol, B. (2002). Consumer trust, value, and loyalty in relational exchanges. Journal of Marketing, 66(1), 15-37. https://doi.org/10.1509/jmkg.66.1.15.18449

So, M. W., \& Sculli, D. (2002). The role of trust, quality, value and risk in conducting e-business. Industrial Management \& Data Systems, 102(9), 503-512. https://doi.org/10.1108/02635570210450181

Stone, R. N., \& Grønhaug, K. (1993). Perceived risk: Further considerations for the marketing discipline. European Journal of Marketing, 27(3), 39-50. https://doi.org/10.1108/03090569310026637

Swaminathan, V., Lepkowska-White, E., \& Rao, B. P. (1999). Browsers or buyers in cyberspace? An investigation of factors influencing electronic exchange. Journal of Computer-Mediated Communication, $5(2)$.

Swanson, E. B. (1974). Management Information System: Appreciation and Involvement. Management Science, 21(2), 178-188. https://doi.org/10.1287/mnsc.21.2.178

Sweeney, J. C., \& Soutar, G. N. (2001). Consumer perceived value: The development of a multiple item scale. Journal of Retailing, 77(2), 203-220. https://doi.org/10.1016/S0022-4359(01)00041-0

Taiwan Network Information Center, TWNIC. (2016). Taiwan broadband Internet use survey. A Summary Report July 2016.

Thurstone, L. L., \& Thurstone, T. G. (1941). Factorial studies of intelligence. Psychometric Monographs, $2,94$.

Vigneron, F., \& Lester, W. J. (1999). A review and a conceptual framework of prestige-seeking consumer behavior. Academy of Marketing Science Review, (1), 1-15.

$\mathrm{Wu}, \mathrm{S}$. I. (2006). A comparison of the behavior of different customer clusters towards Internet bookstores. Information \& Management, 43(8), 986-1001. https://doi.org/10.1016/j.im.2006.09.002

Zaichkowsky, J. L. (1985). Measuring the involvement construct. Journal of Consumer Research, 12(3), 341-352. https://doi.org/10.1086/208520

Zeithaml, V. A. (1988). Consumer perceptions of price, quality, and value: a means-end model and synthesis of evidence. The Journal of Marketing, 52(3), 2-22. https://doi.org/10.2307/1251446

Zeithaml, V. A., Parasuraman, A., \& Malhotra, A. (2005). ES-QUAL: A multiple-item scale for assessing electronic service quality. Journal of Service Research, 7(3), 213-233. 


\section{Copyrights}

Copyright for this article is retained by the author(s), with first publication rights granted to the journal.

This is an open-access article distributed under the terms and conditions of the Creative Commons Attribution license (http://creativecommons.org/licenses/by/4.0/). 